\title{
Development of Learning Chair Designs for Hyperactive Students Based on Cyber Technology in Inclusive Elementary School
}

\author{
Hartini Laswandi, Heni Mularsih
}

\begin{abstract}
Uncomfortable feelings and difficulties in reducing the overactive tendencies of students with special needs appeared as two of the most common problems in inclusive elementary schools. Elaborated, such issues can range from anxiety up to children who constantly interfere with their friends while sitting in the classroom. If not taken seriously, these kind of problems will surely disturb the learning process both for normal pupil and those who need special care in inclusive school. Unfortunately, commonly found study chairs that are used in inclusive school are still based on the design of normal students. Not only that, the design was also made before the advancement of today's cyber technology. Thus, this study aims to develop a design for study chair that can fit the needs of hyperactive students' ergonomics based on anthropometry while utilizing the current state of cyber technology. The use of cyber technology became a key on the study because it provides a good alternative in the design process, since it produces fast, precise and accurate design images. In conducting this study, the writer used the methodology of design function / The Quality Function Deployment (QFD) with ergonomic and anthropometric approaches to determine the dimensions of the chair design for hyperactive students. With such approaches, the writer of this study was able to create a hyperactive student chairs that has specific features such as adjustable armrests, flexible, and footrests with a slider system. With such features, the chair will provide convenience and reduce space for the activity of hyperactive students.
\end{abstract}

Index Terms: Keywords: hyperactive, inclusive, cyber technology, ergonomics, study chairs.

\section{INTRODUCTION}

Adequate learning facilities are crucial both for national as well as inclusive schools at any level. The design process and development of such facilities cover a handfull of stages, such as identifying the needs of pupil's learning process, analyzing design development, synthesizing processes that produce programmed concepts, then design concepts, and implementing designs into technical drawings. In this case, the process started with analyzing the behavorial and emotional character of hyperactive children and render such analysis into a comfortable and suitable learning chair design. This can be challenging, since sitting position is something that is personal. Thus, two questions arose. First, how can we

Revised Manuscript Received on September 22, 2019.

Hartini Laswandi, Department of Design Interior in Universitas Tarumanaara Jakarta 11440 Indonesia, Education of Technology in Universitas Negeri Jakarta 13220, Indonesia. hartini@fsrd.untar.ac.id hartinilaswandi@gmail.com, hartinilaswandi_tp16s3@mahasiswa.unj.ac.id

Heni Mularsih, Department of Education of Technology \& Education of Psychology Universitas Tarumanagara Jakarta 11440, Indonesia. henim@mku.untar.ac.id develop a learning chair design that can be suitable for all hyperactive pupils? And second, how such learning chair design can enhance the learning process of the hyperactive kids, fulfill the ergonomical standards, and will make these children can sit comfortably.

Based on pre research reviewing, there is no design nor development of learning chair for hyperactive students, especially the design that can provide good ergonomics and comfort. Thus, the research team of this paper is interested and feel the urgency in developing such design and creating a specific study by utilizing the cyber technology and that can be applied in the inclusive elementary school. The importance of such study is emphasized when we realize that children spend most, at least 80 percent, of their time in school. In elementary school alone, the pupils have to sit in learning chairs and going through day to day learning process 5 days a week for 6 years. Therefore, we believe that comfortable learning chair is essential and will create a big impact in the children's learning process.

Earlier researches on the design learning of learning facilities were mainly focused on learning facilities for normal school with normal students. Learning chair was studied and developed based on the needs of normal schools. Thus, the learning chair that is currently used by inclusive schools are made for normal students. With this phenomenon, there are several common issues that are found in inculsive schools' learning chair such as: (a) Posture patterns in class chairs are designed for normal students, commonly created with upright postures that was popular back in the 20th century. This position can eventually lead to excessive muscle activity. Not only that, incorrect body posture which press the diaphragm will also impair breathing and speaking ability. (b) learning chairs that is not designed propperly in terms of size and felxibility. Hyperactive children are very mobile so they need propper size and design of learning chair, which can be flexible, strong, and accomodate their different cognitive abilities. (c) Physical stress. For hyperactive students, using classroom furnitor that does not meet the ergonomic standards can lead to physical problems. The problems that haunted those pupuls can range from hampered blood circulation, tense and impaired neck up to back pain. (d) Ineffective learning process. The use of learning chair that is not suitable for hyperactive students can affect the cognitive ergonomics of those pupils. With such situation, hyperactive students could experience difficulties in maintaining conentration and attention, as well as weak memory, which can lead to the lack of academic achievements. Not only that, the problems appeared not only affect the hyperactive kids in the inclusive schools, but also teachers and the other normal students. Therefore, 
this study aims to facilitate the needs of learning chairs specifically designed for hyperactive students. This design study will also be based on the body dimensions and analysis of sitting habit of hyperactive students in inclusive elementary schools in Indonesia.

\section{LITERATURE REVIEW}

\section{A. Learning Facilities}

Learning facilities should be able to support the education programme effectively and facilitate the development of learning environment which enhance the learning experience of both students as well as the teachers. In reality, pupils sit with various habits and position in schools. Learning chairs can be used by children in an upright, tilted, twisted, closed, or open position. Not only that, students also sit while stretching their legs, cross their legs, or move their legs while learning in class. This phenomenon had also been found by a research conducted by Human Environmental Research Organization (HERO, inc). The research, that has been carried out for around 3 decades, found that the performance of workers is influenced by the body ergonomics, working behaviour as well as the working environment. Referring to the study, in terms of learning process in schools, spacious classrooms and good learning facilities will impact the success of learning process [1] [2].

Learning facilities such as tables and chairs have to be scaled well so that they can fit the size of every pupil. It is important since the physical faciliy of a school influence the learning process, learning environment, and eventually the academic result of the students, [4]. The lack of infrastructure and learning facilities will lead to bad performance in a school's environment, [5]. Students tend to like sitting arrangement that is flexible. Learning chair that is comfortable, functional, and dynamic become pedagogical artifacts in the participatory design process, which refers to how educators and students create functional and meaningful learning spaces, [6] Classrooms designed with comfortable and safe seating facilities can support student learning. The design should include appropriate dimensions of the learning chair that is applicable to the learning chair. This is because the right dimension will support the comfort of sitting, safety, and health for students participating in the learning process.

Chair and furniture are necessary facilities in a classroom environment that facilitate pedagogical methods and strategies to increase learning involvement and attention. According to [7], learning is influenced by various physical characteristics of the classroom, including the design of the chair. Pupil's body that is ergonomic will correct body shapes and size for normal students by [8] emphasized the importance of ergonomics. Seat that is not proper will impact the normal musculoskeletal development, will result in poor posture, back pain, neck pain, and other health problems. Normal students can experience reduced brain activity when the body sits wrong and is uncomfortable because students are constantly moving in class. Thus, students with special needs or hyperactivity can increase the risk of back and neck pain, increasingly restless or demotivated to go to school [9].

The learning chair facilities for hyperactive students are sought to nurture students in teamwork and collaboration in the classroom. Furnitures in class should be adjusted to accomodate the various learning activities [10]. For active student learning, it is important to consider class seating arrangements so that students can contribute to collaborative learning and performance. Learning chair facilities both for normal and hyperactive students require a degree of flexibility and mobility to support the goals of active learning and teaching methods [11].

\section{B. Inclusive School}

Inclusive education is a form of education that brings together children with special needs with normal children. In Indonesia, this kind of school was embedded in the broader inclusive education policies including curriculum, recruitment of special teacher (GPK), and inclusive school facilities [12]. The level of involvement of these classmates (normal students), how much they learn and interact with this hyperactive children, that intertwine with how they know and analyze the anxiety of young and professional parents, [13] having holidays together with hyperactive children will contribute significantly in developing connection between children, and how they can accept their hyperactive counterparts, [14]. In developing interventions to provide facilities to improve quality of life among students with special needs, hyperactivity in this context, Author links open overlay panel [15]

\section{Hyperactive Students}

Hyperactive childrens are children that can't concentrate and tend to forget what they have heard and said for less than 10 seconds. Usually, it is hard for them to sit still and they will act as they please stubbornly. Students with Attention Deficit Hyperactivity Disorder (ADHD), a form of hyperactivity in children, experience academic and prolonged disorders, and are underachievers since they find it to be difficult to complete school assignments, [16]. Measurement invariance (MI) for the latent nature of ADHD in various sociodemographic groups in schools related to IQ, and psychiatric diagnosis by [17].

\section{Ergonomics}

Learning environment requires flexible furniture that can balance learning activities for both normal students and students with special needs/hyperactivity. Research development for improvement and results implementation processes in the wider literature into student learning facilities in the classroom [18]. Children are known to spend more than $30 \%$ of their time in school. Most of the class activities include sitting for long periods of time, with little or no rest. Organizational management/OBM applies the principles and methods of student behavior to improve learning performance and individual safety, [19]. An uncomfortable chair can hamper learning process, reduce attention span and concentration, and will result in fatigue, saturation or even pain.

Every attempt has to be made to ensure that children do not have back pain and other musculoskeletal disorders because they sit elongatedly in classroom furniture that is improperly designed, [20]. Ergonomic performance, which is often considered rough during the design phase, can represent a fundamental step in preventing ergonomic problems if it is taken into account since the design phase of the production process initiated, [21]. Student anthropometric measurements are used for furniture

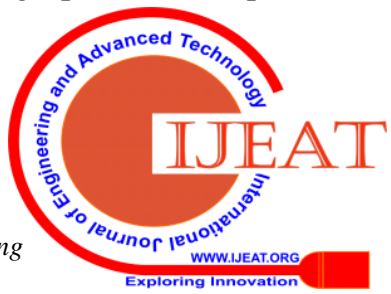


dimensions. Investigations of related anthropometric measures such as height, weight, Body Mass Index (BMI), popliteal height, buttocks popliteal length and hip breath showed that height and body mass index were important factors in sketching the furniture in classroom chairs. The procedure adopted for assessment involves the current school furniture survey, analysis of activities, habits, and estimates of comfort for both normal and hyperactive students.

\section{E. Cyber Technology}

Cyber technology and Additive Manufacturing (AM) are ready to bring a revolution in the way products are designed, produced, and distributed to end users, [21]. The making of computer technology-based or cyber technology with cloud (CBDM) design refers to a service-oriented network product development model where consumers can configure, select and use customized product realization services and resources ranging from computer assisted software to manufacturing system that can be reconfigured, [22].

Research investigates the influence of cyber technology in the future. The effectiveness of design is greatly moderated by the frequency of computer technology utilization [23]. Some advantages that gained through the use of cyber technology in design process include: (a) Data storage. Data that we gathered and used during the design process can be easily stored as well as transfered to other program. (b) Data-In-Transit, all of the data in the design process in the form of text as well as pictures during the design process can be transfered quickly through a server line. (c) Communication during the design process can be conducted easily and fastly. Communication can be done everywhere at anytime through Email, Whatsapp, SMS, Slack, etc. (d) The need to be skilled in the design process. Utilizing high-resolution digital optical technology, will provide effective visual tool for drawing architectural desig,. [24]. The skill (to work quickly and precisly) is needed during all phases of design process including data collection process, design analysis and design concepts. (e) Cyber techonology are effective in maximizing the design experience. Technology that uses digital station twin can minimize the time needed to develop and design interior assembly lines, correct design errors during the design phase, that normally can only be done during the production phase, [21]. Film-based digital technology can create impressive visual design images, that is crystal clear, [20]. Digitalization promotes designers to obtain adequate skills and use the Internet more effectively, [25]

\section{METHODOLOGY}

Participants selected are inclusive elementary school students randomly picked both normal and hyperactive. In collecting data from the participants, the questionnaire used was prepared to identify student requirements. The design method with QFD is used to prioritize design needs. After data has successfully gathered from the participants, various types of anthropometric measurements are discussed to understand the collected data. After that, the steps in the design process for hyperactive student learning chairs are discussed. The procedure for calculating incompatibility between furniture and body dimensions is also displayed in this part of the study. Finally, the design of the learning chair for hyperactive students is explained. This analysis is carried out by using the QFD method to assist the designer in compiling knowledge, taking into account product functions' characteristics, activities or criteria for the use of the product, and points that are aimed to be developed when drawing up the design. The use of cyber technology with 2D programs, applied at the time of data collection, design analysis, technical drawings and data storage.

\section{A. Participants}

Sample of this research consists of three (3) inculsive elementary schools in several areas that represent the amount of inculsive elementary school's population in Indonesia. Hyperactive students in the inculsive elementary schools were also picked for antropometric measurement. Not only that, the dimension of furnitures in the selected inculsive schools are also gatered to determine the incompatibility of currently used furnitures with anthropometric measurements.

\section{B. Prosedures}

The design process include the distribution of quality /QFD functions model. After obtaining all of the needed research permit in inclusive schools, the study was ready to be conducted and focused on the aspect of design requirements. Analysis of learning activities when sitting on hyperactive students was done to obtain the needs of the learning chair facilities.After that, the anthropometric measurements of students with hyperactive disabilities were carried out. The dimension of currently used furniture were also taken to calculate mismatches. The Deployment Quality Function was used as a total quality management tool that represents all structural analysis. The Quality Function Deployment/QFD translates the needs of learning chairs for hyperactive students that has not been fulfilled in inclusive elementary school. The design process considers how to learn to use the chair product by integrating behavior analysis (product behavior and users) with functional analysis.

\section{Design Methodology Refers to Quality Function Deployment /QFD}

Quality Function Deployment / QFD is a total quality management tool that was introduced in Japan in the year of 1972, [26]. This tool is also used in educational institutions and service providers to enhance learning services. The method of distributing quality functions was found based on school requests from customer voice (VOC). Function requirements and qualifications that are designed refer to school requests. The Quality Function Deployment / QFD method is basically based on surveys in public schools and inclusive schools. The specific level of development of the Questionnaire is the first stage of the process of implementing the Quality / QFD Function. There are severeal ways to take surveys in inclusive schools for hyperactive students, and one of them is through questionnaire. The voice of the customer/VOC that is translated is a necessity. The structured process of distributing quality functions is listed below, [26].

\section{Step 1: Questionnaire Development}

In order to gather data as the basis of the questionnaire, the researchers arranged meetings with teachers and parents of hyperactive children and observe how the children sit and learn in classroom, with the mindset of ergonomics. Developing the design of study chair designs for students with special needs, we conducted an analysis of the behavior of 
hyperactive students from the beginning to the end of school. There are around seventeen (17) hyperactive student learning characters that underlie the study chair design analysis. The involvement of cyber technology at this stage is in compiling and searching data to be safer and faster

\section{Step 2: Identifying Customer Requirements}

After questionnaire development, the researchers go on the next step which is identifying customer's requirements from the survey conducted. In this step, the users' voices are translated so that they can be interpreted. The user request requirement underlies the development, and several requirements, which then will be applied. The involvement of cyber technology at this stage is in processing the initial data such as the need for tables, drawing sketches and so on.

\section{Step 3: Determining The Relative Importance of What's}

In this step, the relative importance of What is determined. In order to do so, the characteristic table of Satty's learning activities are used to capture the importance of analyzing the development of study chair designs specific for hyperactive students.

\section{Step 4: Establishing Design Requirements}

In order to determine the design requirements, data on hyperactive student activity and their character of learning were analyzed. Ergonomic and anthropometric measurement studies of hyperactive students were used to create the best design requirements for articulated inclusion school requests. In this step, the main target is to meet the demands of inclusive schools and to get user's convenience.

\section{Step 5: Prioritizing of Design Requirements}

The last step of the process is prioritizing the design requirements. This step decide the design requirements that have to be used in the study chair prduct. In this step, the design requirements are prioritized by observing hyperactive student's activity in class, the approach of anthropometric ergonomy and the learning process of inclusive elementary school.

\section{Anthropometric Measurements}

The anthropometric dimensions of hyperactive student are used as a keyword during ergonomic furniture designs. Anthropometric trace are collected by observing sitting and standing position of hyperactive students while using the study table. Methods of measurement, observation, and measurement were carried out to ensure that hyperactive students will sit upright and students' legs are perpendicular to the bottom while using the chair. Beside that, anthropometric measurement was also used to measure the seating height of hyperactive students. In this context, the researchers calculated the vertical distance from the horizontal sitting surface to the head. This measurement is used to determine the vertical clearances needed for a sitting position. Not only the seating hight, eye height is also measured with this method in this study. The measurement was done by Calculating the vertical distance from the surface that sits horizontally to the eye. The object that students see should appear below the horizontal plane determined by the height of their eye. Lastly, anthropometric measurement was used to measure the height of the children's shoulder. The process was carried out by Calculating the vertical distance from the horizontal seated surface to the acromion (Figure 1 and 2). Image Source: [27]

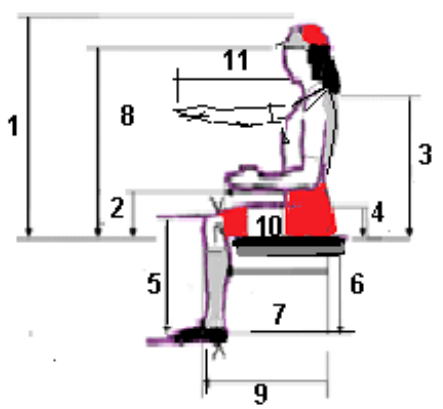

Fig 1: Measured Anthropometric Data.

Legend: (1) Height size sit up to the head, (2) High elbows sit from the buttocks, (3) Sitting size to shoulder height, (4) Thigh permit, (5) Height of the knee from the foot, (6) Popliteal height from the foot, (7) Buttock-popliteal length, (8) Height of the eye from the stand, (9) Butt-knee length, (10) Long arms - hands (11) Long stretch of hand

- The size of hip's width: is to determine the maximum horizontal distance between the hips of a student in a sitting position on a chair.

- Elbow height to elbow: is the horizontal distance across the surface of the elbow to the side calculated. This size is to find the width of the seat back and the distance between the armrests.

- Thigh distance: is the vertical distance from the student sitting horizontally to the maximum point on the thigh.

- The knee height: is the vertical distance from the floor to the upper thigh surface $\left(90^{\circ}\right.$ knee flexion is required).

- Butt knee length: the horizontal distance from the front of the knee to the back of the stand.

- The length of the popliteal buttocks: horizontal distance from the posterior surface of the buttocks to the popliteal surface. This length is calculated up to a $90^{\circ}$ angle size.

- Popliteal height is the vertical distance from the surface of the footing to the popliteal site. The popliteal height must be shorter than the height of the chair [26].

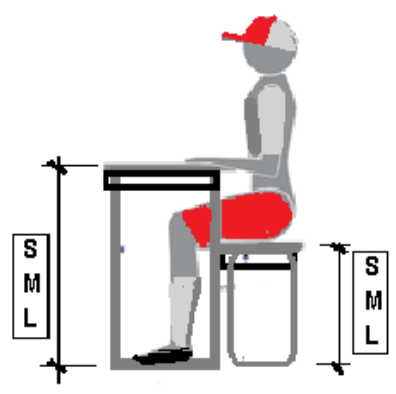

Fig 2 : Measured Anthropometric Data, for seat height a) Sizemark S: small, seat height $380-400 \mathrm{~mm} /$ table $550-600$, b) Sizemark M: Medium, seat height $430-450 \mathrm{~mm} / \mathrm{table}$ 600-750 mm, c) Sizemark L: large, seat height $460-480 \mathrm{~mm}$ /table 700-800

Learning chair furniture and body dimensions: Ergonomic and anthropometric rules should be used to design and determine the range of furniture dimensions in the study chair. The anthropometric measurements of hyperactive students, which are related to the dimensions of furniture, can be used to identify both compatibiligy and incompatibility of the study chair. The following equation is usually used:

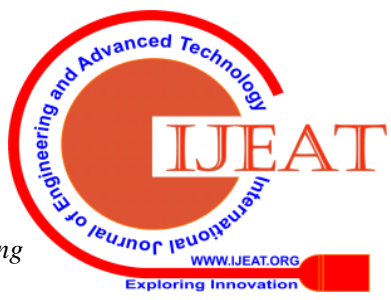


Popliteal Height $(\mathrm{PH})$ Seat Height $(\mathrm{SH})$ : The height of the chair must be balanced with the respect to the height of the popliteal $(\mathrm{PH})$. Knee flexibility is needed so that the lower leg frames do not exceed the extreme point of $30^{\circ}$ against the vertical, [28]. Seat height (SH) must be lower than Popliteal Height $(\mathrm{PH})$ so that the lower limbs form $5^{\circ}-30^{\circ}$ with the vertical and thigh edge of the thigh bone around $95^{\circ}$ and 120 $\circ$. Seat height $(\mathrm{SH})$ does not have a size higher than $4 \mathrm{~cm}$ or $88 \%$ of Popliteal Height (PH) to maintain a strategic distance from pressure in the cheek area [29] [30].

\section{RESULTS AND FINDINGS}

The results of the analysis of the learning characteristics of hyperactive / ADHD students and their handling with exclusive school facilities can provide insights in developing the answer towards how to facilitate learning for inclusive schools, (Table 1)

\section{Hyperactive Student Learning Characteristics}

Table 1. Hyperactive student learning characteristics and furniture needs

\begin{tabular}{|c|c|c|}
\hline $\begin{array}{l}\text { Hyperactive } \\
\text { Student } \\
\text { Learning } \\
\text { Characterist } \\
\text { ics }\end{array}$ & $\begin{array}{l}\text { Hyperactive } \\
\text { treatment }\end{array}$ & Options for the Furnit \\
\hline $\begin{array}{l}\text { Hyperactive } \\
\text { students are } \\
\text { Never shut } \\
\text { up }\end{array}$ & $\begin{array}{l}\text { Choose } \\
\text { learning } \\
\text { activities } \\
\text { according to } \\
\text { their interests } \\
\text { so that their } \\
\text { desires are } \\
\text { channeled in a } \\
\text { positive } \\
\text { direction }\end{array}$ & 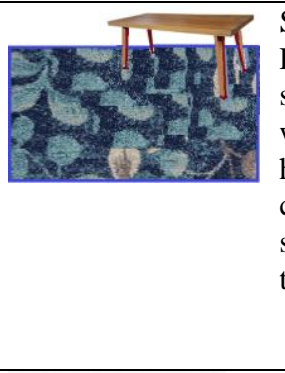 \\
\hline
\end{tabular}

\begin{tabular}{ll}
\hline $\begin{array}{l}\text { Active in } \\
\text { motion }\end{array}$ & $\begin{array}{l}\text { Choose } \\
\text { positive and } \\
\text { useful } \\
\text { learning } \\
\text { activities }\end{array}$
\end{tabular}

Hyperactive Give an students are example to difficult to children how tell

to behave properly and correctly.

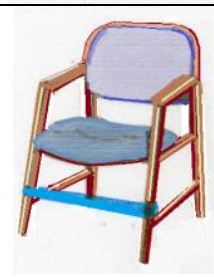

Schools

Provide

Design a chair with an

armrest, while learning to limit motion Schools Provide Seat design with armrest, foam seat and foamy backrest, while learning to be more comfortable

\begin{tabular}{ll}
\hline Destroyer/ & Makes him \\
Destructive & $\begin{array}{l}\text { look around } \\
\text { who is very } \\
\text { appreciative }\end{array}$
\end{tabular}
appreciative

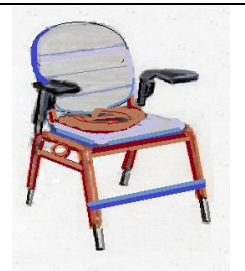

Schools

Provide The design of the chair with armrest, foam seat and foamy backrest, is equipped with seat belt when learning to reduce activity

\begin{tabular}{ll}
\hline Impulsive & $\begin{array}{l}\text { Allowing the } \\
\text { child to feel } \\
\text { things that are } \\
\text { dangerous but } \\
\text { in a mild } \\
\text { stage. }\end{array}$
\end{tabular}

Schools

Provide The

seat design

with foam seat and foamy

backrest,

equipped with

leg straps

when learning

to reduce

activity

\begin{tabular}{ll}
\hline \multirow{3}{*}{ Tireless } & Select \\
& activities \\
& according to \\
& their interests \\
& so that their
\end{tabular}

so that their

Schools

Provide a

special space

when

wishes are

hyperactive

channeled in a

children are

positive

saturated, in

direction.

the classroom

with puzzle

carpets

\begin{tabular}{|c|c|}
\hline $\begin{array}{l}\text { Low } \\
\text { intellectuali } \\
\text { ty }\end{array}$ & $\begin{array}{l}\text { Direct the } \\
\text { completion of } \\
\text { learning tasks } \\
\text { with their }\end{array}$ \\
\hline
\end{tabular}

Sensory

holder for

comfort and

more

concentration

\begin{tabular}{|c|c|c|}
\hline $\begin{array}{l}\text { Hyperactive } \\
\text { students } \\
\text { Can't Calm } \\
\text { down }\end{array}$ & $\begin{array}{l}\text { Provide } \\
\text { activities that } \\
\text { require } \\
\text { gradual calm } \\
\text { so that } \\
\text { children begin } \\
\text { to adapt to } \\
\text { these activities }\end{array}$ & $\begin{array}{l}\text { The design of } \\
\text { the chair with } \\
\text { a sensory } \\
\text { foam seat, } \\
\text { equipped with } \\
\text { leg straps } \\
\text { when learning } \\
\text { to reduce } \\
\text { activity }\end{array}$ \\
\hline $\begin{array}{l}\text { Hyperactive } \\
\text { students } \\
\text { Don't like to } \\
\text { be friends } \\
\text { much }\end{array}$ & $\begin{array}{l}\text { Help him } \\
\text { mingle with } \\
\text { his age friends } \\
\text { and have the } \\
\text { same interests }\end{array}$ & $\begin{array}{l}\text { Schools } \\
\text { Provide a } \\
\text { special space } \\
\text { when } \\
\text { hyperactive } \\
\text { children are } \\
\text { saturated, in the } \\
\text { classroom with } \\
\text { puzzle carpets }\end{array}$ \\
\hline $\begin{array}{l}\text { Hyperactive } \\
\text { students are } \\
\text { impatient }\end{array}$ & $\begin{array}{l}\text { Give activities } \\
\text { that he is } \\
\text { interested in } \\
\text { but requires } \\
\text { high patience }\end{array}$ & $\begin{array}{l}\text { Schools } \\
\text { Provide Chair } \\
\text { design with } \\
\text { sensory foam } \\
\text { stand, } \\
\text { equipped with } \\
\text { foot strap }\end{array}$ \\
\hline $\begin{array}{l}\text { Hyperactive } \\
\text { students } \\
\text { like to fight }\end{array}$ & $\begin{array}{l}\text { Hyperactive } \\
\text { students are } \\
\text { given an } \\
\text { example of } \\
\text { cause and } \\
\text { effect if the } \\
\text { child fights } \\
\text { back. this aims } \\
\text { to apply the } \\
\text { practice of } \\
\text { direct practice } \\
\text { so that it is } \\
\text { easily } \\
\text { absorbed by } \\
\text { children. }\end{array}$ & $\begin{array}{l}\text { Schools } \\
\text { Provide } \\
\text { special space } \\
\text { when } \\
\text { hyperactive } \\
\text { children are } \\
\text { saturated, in } \\
\text { the classroom } \\
\text { with carpets }\end{array}$ \\
\hline
\end{tabular}
children. 


\begin{tabular}{ll}
\hline $\begin{array}{l}\text { Hyperactive } \\
\text { students are } \\
\text { out of focus }\end{array}$ & $\begin{array}{l}\text { Hyduents are } \\
\text { given } \\
\text { activities that } \\
\text { require the } \\
\text { child to focus } \\
\text { on one thing. }\end{array}$
\end{tabular}

$\begin{array}{ll}\text { Hyperactive } & \text { Hyperactive } \\ \text { students } & \text { students are } \\ \text { like things } & \text { given games } \\ \text { too } & \text { that are not } \\ \text { atractive } & \text { too dangerous }\end{array}$

attractive

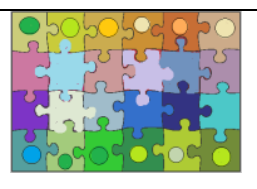

School
Provide a
chair design
with armrests,
foam seat and
foamy
backrest,
equipped with
seat belt when
learning to be
more focused

Schools

Provide a

when

hyperactive

children are

saturated, in

class with

puzzle carpets

\begin{tabular}{ll}
\hline Hyperactive & Hyperactive \\
Students & students are \\
Care for & taught \\
Yourself & learning by \\
& doing and \\
& causal \\
& techniques.
\end{tabular}

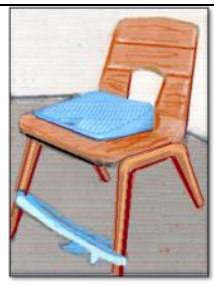

The school

made a chair

design with a

sensory stand special space

Hight armrest on the chair
Long armrest
Size of the armrest width
The back seat of armrest from
the front
Seat back height
Back seat recline angle
High size foot climbing

7" $-9 "(17.78 \mathrm{~cm}-22.86 \mathrm{~cm})$

8 " minimum $(20.32 \mathrm{~cm})$

2 " average $(5.08 \mathrm{~cm})$

$2 "-3 "(5.08 \mathrm{~cm}-7.62 \mathrm{~cm})$

$12 "-18 ”(30.48 \mathrm{~cm}-45.72 \mathrm{~cm})$

$0^{\circ}-5^{\circ}$

$6 "-8 "(15.24 \mathrm{~cm}-20,32 \mathrm{Cm})$

\section{A. Chair Design For Hyperactive Students}

The design of the study chair for the proposed hyperactive students has the correct dimensions to be a comfortable and safe learning facility. To achieve such design, the researchers went on the process of Data collection design, analysis of design development and work drawing techniques of cyber-based 2D computer program technology. Through such processes, it was obtained a design of chairs for hyperactive students that has armrests and lumbar supports that can be set up and down, strong but flexible footrests for freer legs movement, sensory seat that is soft and comfortable for students with high body dimensions and safety belt that can be used to restrict the movements of hyperactive kids if they need to concentrate on learning. The design of the learning chair for hyperactive students after going through the analysis process is shown in the figure below; (Figur 3, 4, 5, 6).

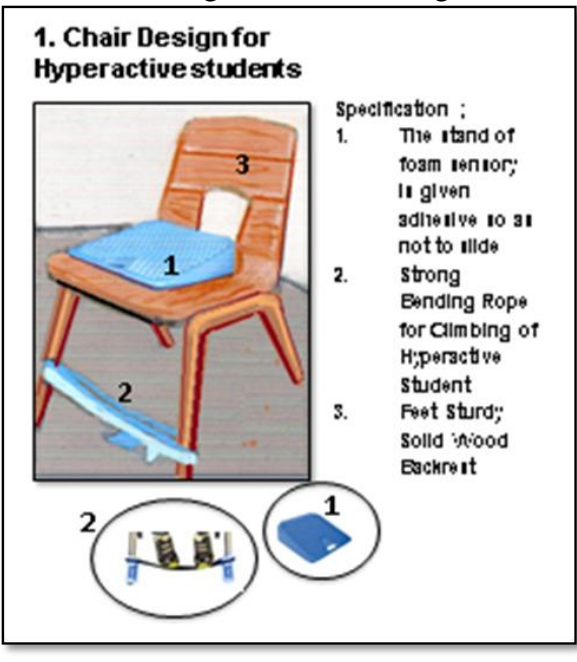

$\begin{array}{ll}\begin{array}{l}\text { Hyperactive } \\ \text { Students are } \\ \text { late } \\ \text { physical } \\ \text { development }\end{array} & \begin{array}{l}\text { Hyperactive } \\ \text { students are } \\ \text { given therapy, } \\ \text { and school } \\ \text { and find talent } \\ \text { that he can or } \\ \text { does he } \\ \text { possess }\end{array}\end{array}$

\begin{tabular}{ll}
\hline Hyperactive & Hyperactive \\
students & students are \\
cannot & given a time \\
control & limit to play \\
movement & and apply a \\
& schedule \\
& system
\end{tabular}

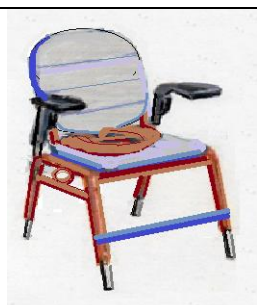

School make

The design of the chair with the armrest, foam seat and foamy backrest, is equipped with seat belt when learning to be more focused

\begin{tabular}{|c|c|c|c|}
\hline $\begin{array}{l}\text { Hyperactive } \\
\text { students are } \\
\text { easily upset }\end{array}$ & $\begin{array}{l}\text { Hyperactive } \\
\text { Students are } \\
\text { given games, } \\
\text { or activities } \\
\text { that require } \\
\text { high patience }\end{array}$ & 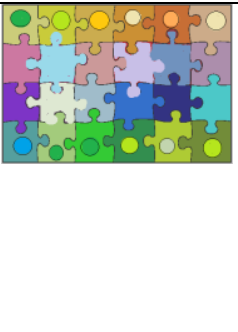 & $\begin{array}{l}\text { Schools } \\
\text { Provide a } \\
\text { special space } \\
\text { when } \\
\text { hyperactive } \\
\text { children are } \\
\text { saturated, in } \\
\text { class with } \\
\text { puzzle carpets }\end{array}$ \\
\hline
\end{tabular}

Table 2. Dimension of chair design for Hyperactive students

\begin{tabular}{|c|c|}
\hline Position & Unit Dimension \\
\hline Wide seat seat size & $16 "-20$ “ (40.64 cm - 51 cm) \\
\hline Length of seat belt & $25 “-30 ”(65 \mathrm{~cm}-75 \mathrm{~cm})$ \\
\hline Seat size dept & $15 ”-20 “(38.1 \mathrm{~cm}-51 \mathrm{~cm})$ \\
\hline Chair height from floor, & $16 "-20 “(40.64 \mathrm{~cm}-51 \mathrm{~cm})$ \\
\hline $\begin{array}{l}\text { Slope angle of seat front to } \\
\text { rear seats }\end{array}$ & $5^{\prime \prime}$ to $8^{\circ}\left(12.7 \mathrm{~cm}\right.$ to $\left.8^{\circ}\right)$ \\
\hline
\end{tabular}

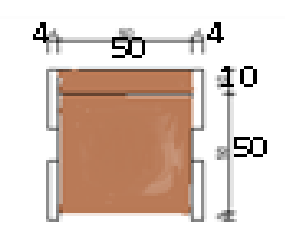

neerent
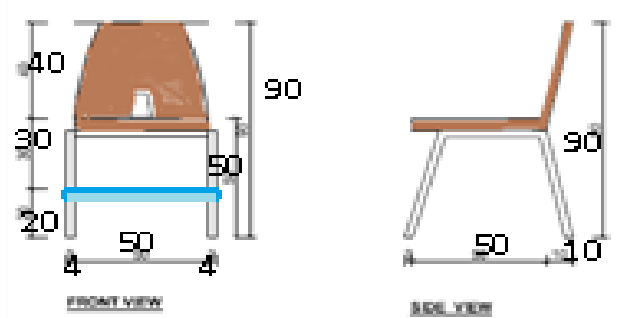

Chal Deshon for Hilperactlve Student 1

Fig 3 : Chair design for hyperactive students (1)

Published By:

Blue Eyes Intelligence Engineering

\& Sciences Publication 

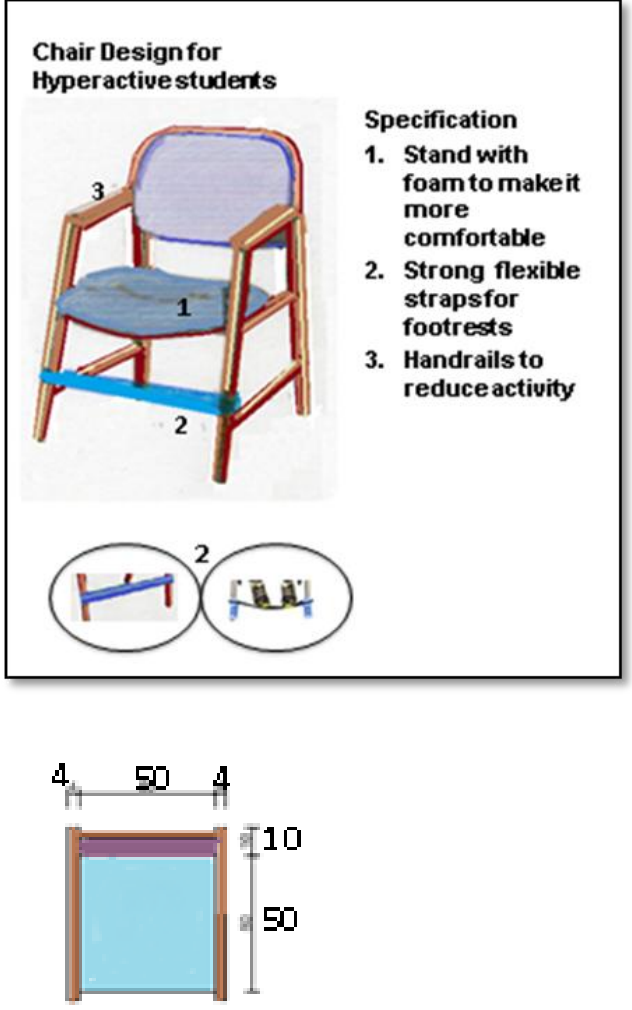

Neveren
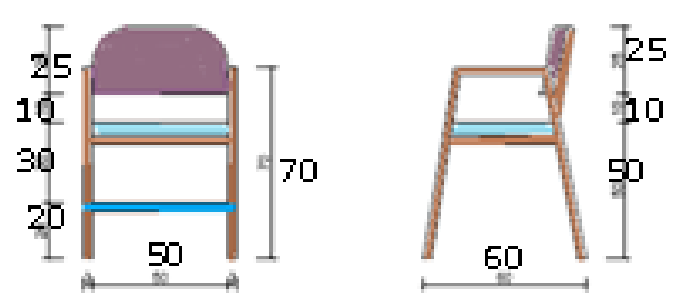

enowrire

soe vrw

Chalr Deslan for Mlloeractive Student 2

Fig 4 : Chair design for hyperactive students (2)

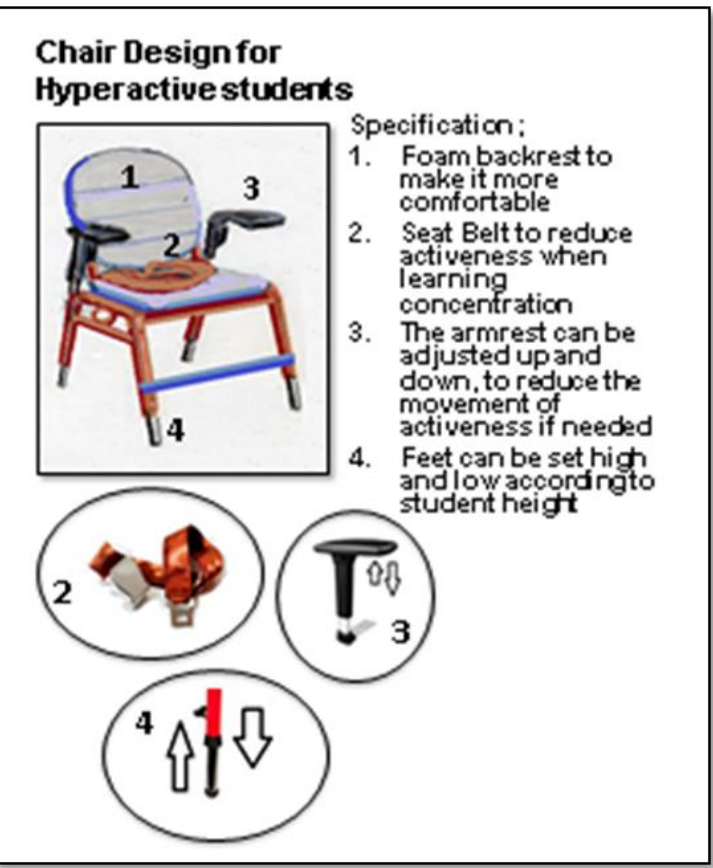

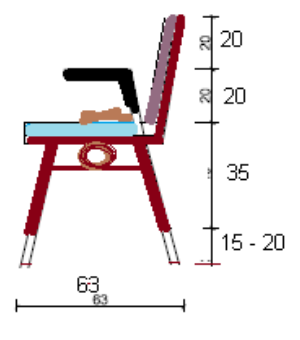

SIDE VIEW

Fig 5 : Chair design for hyperactive students (3)
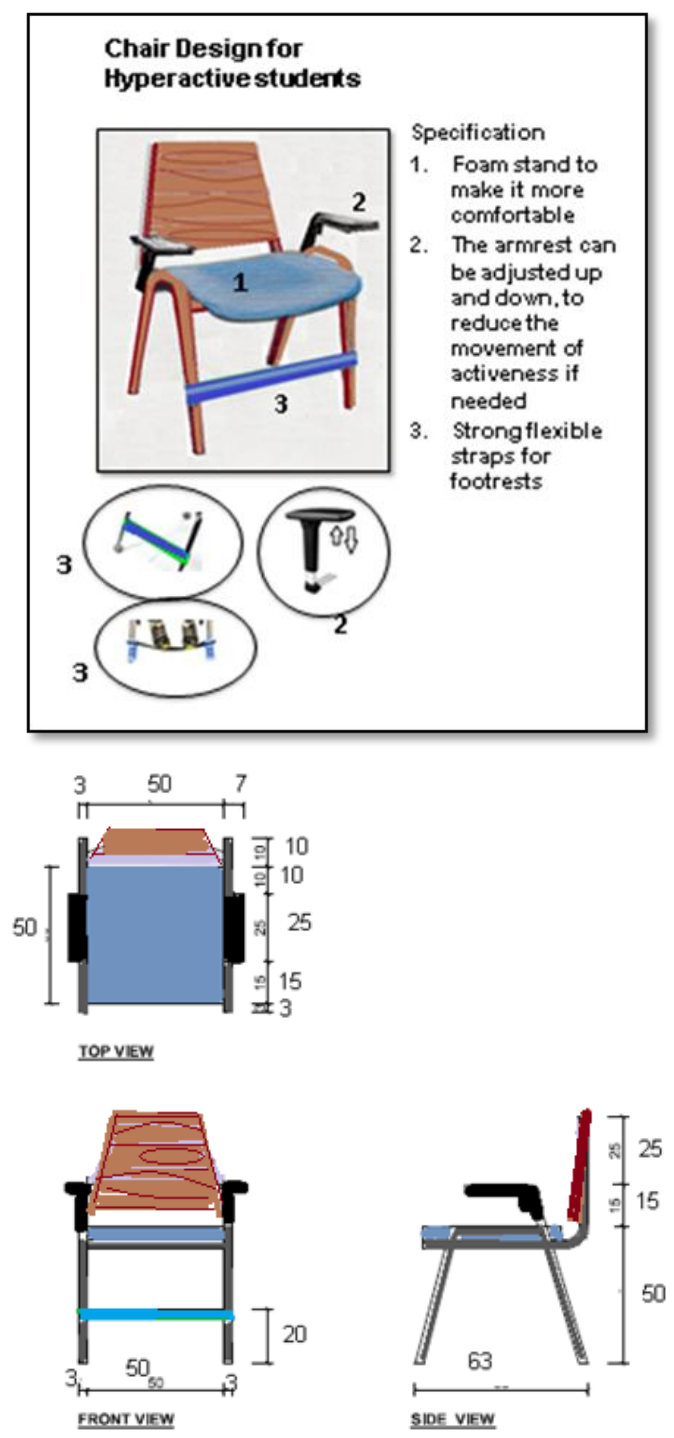

Fig 6 : Chair design for hyperactive students (4)

\section{Implications for Developing Study Chair Designs for Hyperactive Students}

Learning chairs for hyperactive students are important in inclusive schools, since it provides support for learning processes. For safety design, it is

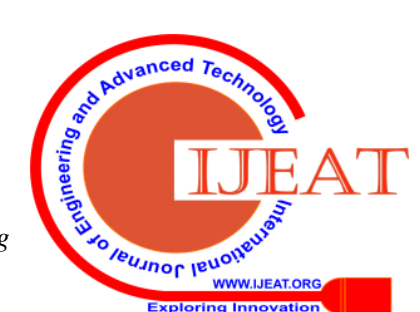


important to understand optimal parameters of student hyperactivity and over-activities such as elbow-ground distance, popliteal height, and range angle, [31]. The main objective is to contribute to the success of inclusive schools. For this purpose, it must consist of:

1- Seats that are suitable for inclusive school learning activities;

2- Seats that support hyperactive student learning styles;

3- Chairs that meet students' physical needs to help them stay healthy, comfortable, and be engaged in learning;

4- Chairs that maximize function for learning for hyperactive students

\section{Flexibility \\ Adaptability and mobility}

- The seat design that is comfortable needs to be flexible. It should be easy to adapt to and easy to move with, can function for a variety of sitting activities, should be easy to be reconfigured in terms of rows, clusters and circles, and can be easily stored or packed, especially for long-term use in school. The chair design should accommodate hyperactive students in centralized, collaborative, and supportive learning and groups as well as enhancing the benefits of technological advancements and teaching methods.

Variety

- Design learning chairs for hyperactive students that are appropriate to the needs for the character of individual work, for group work, and interaction with the teacher;

- Design learning chairs for hyperactive students who support a variety of skills activities, comfortable styles, and learning needs;

Activate technology

- Study chairs for hyperactive students that accommodate and support the use of current technology (eg laptops, mobile devices, whiteboards, etc.) to support student learning and teaching

- Learning chairs for hyperactive students with ergonomics that are wide enough to accommodate students who are on the move.

- Learning chairs for students are hyperactive which allows proper ergonomics and comfort when using learning media. Chair design that supports the productivity of hyperactive students so that they are not left behind by other normal students.

Ergonomics and comfort

- Design learning chairs for hyperactive students designed to fit ergonomically for hyperactive students with the size and proportion needed and support learning styles

- Design of learning chairs for hyperactive students designed to increase comfort, reduce hyperactive behavior and concentration during the period of use during class;

- Chair design that adjusts to the height of hyperactive students, the weight and task of hyperactive students, so it is convenient to take part in quiet learning;

Health and safety
- Learning chairs for hyperactive students are easy to clean and sanitize regularly because hyperactive students usually have direct contact with general students and teachers and many other users;

- Learning chairs for hyperactive students that reduce the active movement of students but remain comfortable so as to reduce anxiety. With comfortable chairs, hyperactive students are not nervous when concentrating. and focus, beneficial for physical health and calm.

- Choosing the right color for learning chairs for students who are hyperactive not only helps determine the purpose of calm/ but also helps students add sensory stimulation and the impact on learning and health. Color can affect emotional stability, focus or attention, cooperative attitude, support productivity, regular communication, and focus on learning.

\section{B. Discussion and Recomendation}

\section{General Discussion}

Development of study chair designs for hyperactive students in facilitating learning process has not been considered and provided by stakeholders in inclusive elementary schools. The size, and other possible characteristics, of study chair furniture of countries across the world differs with anthropometric characteristics of hyperactive students in Indonesia. Developmental research shows that the proposed furniture dimensions are more precise and more specific than existing study chair. The dimensions of the study chair proposed for hyperactive students have special specifications, especially on the armrests, seat belts, and chair legs. Modified study chairs design for hyperactive students in inclusive primary schools for the needs of students with flexible dimensions (fat students, moderate as well as thin students).

\section{Unique Contribution}

The main objective of this study is to re-study the concept of learning chair for hyperactive students in an ergonomic inclusive elementary school from a new perspective. The notable things listed on the research are:

- The QFD methodology helps designers learn to make appropriate connections between the demand of student hyperactivity and design requirements to overcome their shortcomings and limitations.

- The design of study chair is in accordance with the demands of hyperactive student, such as armrests, proper lumbar support size, flexible but strong footrests, seat belts if needed and a system of low-height adjustable legs.

- The right allocation of study chairs for hyperactive students, which is modified with quality, safety, and comfort, is preferred.

- The involvement of cyber technology in designing learning facilities for hyperactive students is very important in the QFD method because the design results are faster, more precise and accurate.

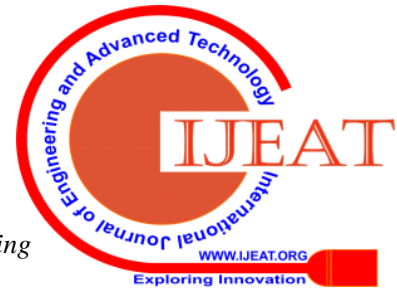




\section{RECOMENDATION}

Researchers who developed the design in this study have several recommendations for providing better learning chair facilities for hyperactive students in inclusive schools.

a. The design of hyperactive students' chair should be comfortable, safe and strong.

b. The design of learning chairs for hyperactive students requires flexible armrests which can go up and down if it is needed.

c. Safety belts are provided if needed when hyperactive students need to concentrate on learning.

d. Seat mounts are equipped with soft sensory pads, helping students who are hyperactive to remain calm.

e. A solid and flexible footing is developed, considering that students' feet should be more ergonomic.

f. Learning chairs' construction must be strong.

g. Study chairs for hyperactive students must have the best aesthetics, innovative features, and colors with calming effects.

h. Cyber technology can be a good alternative to the design process because it produces design images that are fast, precise, and accurate.

i. The development of facility's designs also needs to consider the use of technology in education for students in the classroom

\section{CONCLUSION}

In conclusion, this design development study aims to facilitate the design of learning chairs for hyperactive students, which consider the body dimensions, analysis of ergonomic and sitting activities during learning in inclusive elementary schools in Indonesia. This research was triggered by the unavailability of study chairs designed for hyperactive students in inclusive elementary schools in Indonesia. In developing the design of learning chair for hyperactive students, there are several specifications that have to be fulfilled. The specifications include armrests and lumbar support that can be set up and down, footrests that are strong but flexible for legs movement, soft and comfortable sensory seat, low height adjustable foot design for students with high body dimensions, and seat belts if needed for hyperactive students to be able to concentrate more on learning. The findings of this study also show clearly that the design of study chairs for hyperactive students in inclusive elementary schools in Indonesia must be made in accordance with anthropometric ergonomics assessments to meet the needs of sitting activities during the learning process in the classroom. The design of study chairs for hyperactive students is sought to be comfortable, safe and support the concentration of hyperactive students while studying in class.

Cyber technology can be a good alternative to the design process because it produces design images that are fast, precise, and accurate. 2D and 3D programs are recommended to be used in the design process, and in this case developing design learning facilities. Development of learning facilities design should also consider the use of technology for educational purpose that students in the classroom often use. Extensive research on the development of learning facilities with the involvement of cyber technology is needed so that the user convenience is increasingly fulfilled in inclusion schools in Indonesia.

\section{ACKNOWLEDGEMENT}

The author would like to thank the Director of Faculty of Art and Design Tarumanagara University Jakarta, Director of Research and Community Service/DPPM and Universitas Negeri Jakarta/UNJ for their countless support. This research work supported the Project AIMC-2019-SSH-1398, which is supported by Universitas Tarumanagara Jakarta and Universitas Negeri Jakarta/UNJ. Thank you to my son Ranggga E.S. which helped researchers in this writing.

\section{REFERENCES}

[1] Mbanwi, R.P.E, (2018). The Impact of School Facilities on Teaching and Learning in Presbyterian Secondary Schools in the SW of Cameroon, Int. J. Trend Sci. Res. Dev., vol. 2, no. 6, pp. 1427-1437.

[2] Hanggara,A.S. D.Soegiyanto, and Sulaiman, (2019). Learning infrastructure facilities for physical education , sports and health public elementary schools, J. Phys. Educ. Sport., vol. 8, no. 1, pp. 26-32..

[3] Nepal, B. and Maharjan, R. (2017). Researcher Observational Analysis of the Role of Educational Facilities on Students' Achievement, J. Adv. Acad. Res., vol. 2, no. 1, pp. 26-39.

[4] Nepal, B. and Maharjan, R.(2015 ). Effect of School's Physical Facilities on Learning and Outcomes of Students in Nepal, J. Stud. Manag. Plan., vol. 1, no. 6, pp. 266-279,.

[5] Ilomo, O.and Mlavi, B. (2016). The Availability of Teaching and Learning Facilities and Their Effects on Academic in ward secondary School in muheza- Tanzania, Int. J. Educ. Res., vol. 4, no. 6 , pp. 571-582.

[6] Kallio, J. M. (2018). Participatory Design of Classrooms Infrastructuring Education Reform in K - 12 Personalized Learning Programs, J. Learn. Spaces, vol. 7, no. 2, pp. 35-49..

[7] Adigeb, P. A., Anake, P. M. and Undie, A. A. (2017). European Journal of Education Studies The Impact Of Educational Facilities On Students ' Teaching / Learning Process In Abeokuta , Ogun State, Nigeria : Need For Counselling Approaches," pp. 611-626. [8] Cheung Chan, T. (2009). Do portable classrooms impact teaching and learning?," J. Educ. Adm., vol. 47, no. 3, pp. 290-304.

[9] Yildirim, K,. Capanoglu, A. and Cagatay, K. (2011). The effects of physical environmental factors on students' perceptions in computer classrooms, Indoor Built Environ., vol. 20, no. 5, pp. 501-510.

[10] Ibrahim, N. M. Osman, M. M., Bachok, S.and M. Z. Mohamed, (2016). Assessment on the Condition of School Facilities: Case Study of the Selected Public Schools in Gombak District, Procedia - Soc. Behav. Sci., vol. 222, pp. 228-234..

[11] Wilson, G. and Randall, M. (2012). The implementation and evaluation of a new learning space: A pilot study, Res. Learn. Technol., vol. 20, no. 2 .

[12] Muazza, M., Hadiyanto, H., Heny, D., Mukminin, A., Habibi, A and Sofwan, M. (2018). Analyses of inclusive education policy: A case study of elementary school in Jambi, J. Kependidikan Penelit. Inov. Pembelajaran, vol. 2, no. 1, p. 1 .

[13] Prof.ass.Dr.Gaxhiqi B., Problematic behavior of students with autism in the classroom Prof . ass . Dr . Behxhet Gaxhiqi Faculty of Education, University of Gjakova Abstract 1 . Introduction a Chronological analysis of the problem of autism in children..

[14] Samara, E. and Ioannidi, V. (2019). The use of leisure time as a structured pedagogical intervention to prevent and mitigate behavioral problems . A case presentation from the point of view of informal learning and ed ... The Use Of Leisure Time As A Structured Pedagogical Intervention To Prevent And Mitigate Behavioral Problems - A Case Presentation From The Point Of View Of Informal Learning And Education," no. April, 2019.

[15] Paulraj, S. J. P. V., Alwi, N. A. B.and Vetrayan, J. (2016) Emotional Behaviour among Autism and Typically Developing Children in Malaysia, Procedia - Soc. Behav. Sci., vol. 222, pp 28-35. 
[16] Merrill B.M., Morrow, A.S., Altszuler, A.M., Macphee, F.L., Gnagy, E.M., Greiner, A.R., Coles, E.K., Raiker, J.S., Coxe, S., Pelham, W.E., (2017). Improving homework performance among children with ADHD: A randomized clinical trial, J. Consult. Clin. Psychol., vol. 85, no. 2, pp. 111-122.

[17] Cogo-Moreira, H., Lucio, P.S., Swardfager, W., Gadelha, A., Mari, J.J., Miguel, E.C., Rohde, L.A., Salum, G.A., (2019). Comparability of an ADHD Latent Trait Between Groups: Disentangling True Between-Group Differences From Measurement Problems, J. Atten. Disord., vol. 23, no. 7, pp. 712-720.

[18] Morieson, L., Murray, G., Wilson, R., Clarke, B. and Lukas, K. (2018). Belonging in Space: Informal Learning Spaces and the Student Experience," J. Learn. Spaces, vol. 7, no. 2, pp. 12-22.

[19] Fatolitis, P. G (2019). Behavior-based Safety m Effectiveness and Culture: A Brief Review and Update, J. Ergon., vol. 08, no. 06, pp. 6-7.

[20] Jean, H. (2019). European Journal of Open Education E-learning Studies Character Education Through ( Analysis Of A Film: Freedom Writer By Richard Lagravenese, Starred By Hillary Swank ), pp. 1-9.

[21] Caputo, F., Greco, A., Fera, M. and Macchiaroli, R. (2019). Digital twins to enhance the integration of ergonomics in the workplace design, Int. J. Ind. Ergon., vol. 71, no. August 2018, pp. 20-31.

[22] Wu, D., Rosen, D. W., Wang, L. and Schaefer, D. (2015) Cloud-based design and manufacturing: A new paradigm in digital manufacturing and design innovation, CAD Comput. Aided Des., vol. 59, pp. 1-14.

[23] Parsons, C. S. (2018). Learning the Ropes: The Influence of the Roundtable Classroom Design on Socialization Engagement Feedback and Socialization, J. Learn. Spaces, vol. 7, no. 2, pp. 23-34.

[24] Matthews, L.and Perin, G. (2019). Exploiting ambiguity: The diffraction artefact and the architectural surface, Int. J. Archit. Comput., vol. 17, no. 1, pp. 103-115.

[25] Nikolaos, K.. Tzafea, O.and Thanos, T. (2019), European Journal of Open Education and E-learning Studies University Students' Skills In Using The Internet For Educational Purposes And The Digital Divide, pp. 60-72.

[26] Kapuria, T. K. (2018). Ergonomic Design of Table and Chair based on QFD and Anthropometric Measurement and improved Facility Layout, Ergon. Int. J., vol. 2, no. 3.

[27] Ismaila, S., Musa, A., Adejuyigbe, S. and Akinyemi, O. (2013) Anthropometric Design of Furniture for Use in Tertiary Institutions in Abeokuta, South- Western Nigeria, Eng. Rev., vol 33, no. 3, pp. 179-192.

[28] Molenbroek, J. F. M., Kroon-Ramaekers, Y. M. T. and. Snijders, C. J (2003). Revision of the design of a standard for the dimensions of school furniture, Ergonomics, vol. 46, no. 7, pp. 681-694.

[29] Parcells, C., Stommel, M. and. Hubbard, R.P. (1999). Mismatch of classroom furniture and student body dimensions," J. Adolesc. Heal., vol. 24, no. 4, pp. 265-273.

[30] Ray, P. K. and Maiti, J. (1999), Managing the Asian Century Ergonomic Design of Products and Worksystems-21st Century Perspectives of Asia.

[31] Bora, S., Balerao, Y., Goyal, A., Chakrabaru, D, Chen, D, Bao, N., Niu, X., Garg, A., (2019). Computation of safety design indexes of industry vehicle operators based on the reach angle, the distance from elbow to ground and the popliteal height, Int. J. Ind. Ergon., vol. 71, no. May 2018, pp. 155-164.

\section{AUTHORS PROFILE}

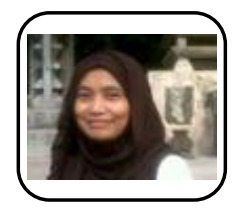

Hartini Laswandi Interior design \& educational technology study programs, doctoral can in Universitas Negeri Jakarta, researchers about learning facilities, public interior space designers and residences. Organization member ADRI, HDII, received master and doctoral scholarships. Secretary of study program 2006-2014.

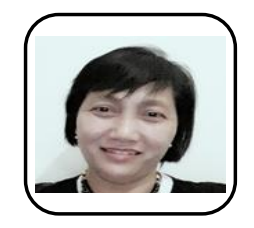

Heni Mularsih Post-graduate programs interpreting educational psychology, doctorate in educational technology, researchers in the educational psychology and educational technology. Undergraduate education pursued is the education of psychology and educational technology. Organization member ADRI, IPTPI, MLI

and H IMPSI. 